\title{
Spor Tükenmişliği Envanteri’nin Türk Kültürüne Uyarlanması ve Psikometrik Özellikleri*
}

\author{
An Adaptation Study of Sport Burnout Inventory into Turkish Culture and
}

\author{
ORİJINAL ARAŞTIRMA/ \\ ORIGINAL RESEARCH
}

\author{
Zekeriya ÇAM ${ }^{1, \dagger}$ \\ Ferhat KARDAŞ² \\ Mustafa EŞKISU ${ }^{3}$ \\ Sedat GELIBOLU ${ }^{4}$
}

${ }^{1}$ Muş Alparslan Üniversitesi, Muş, http://orcid.org/0000-0002-2965-2390

${ }^{2}$ Van Yüzüncü Y1l Üniversitesi, Van, http://orcid.org/0000-0003-3386-3956

${ }^{3}$ Erzincan Binali Yıldırım Üniversitesi, Erzincan, http://orcid.org/0000-0002-7992-653X ${ }^{4}$ Muş Alparslan Üniversitesi, Muş, http://orcid.org/0000-0002-9451-7435

Yayın Bilgisi

Gönderi Tarihi: 13.12.2018

Kabul Tarihi: 17.06.2019

Online Yayın Tarihi: 30.06.2019

\section{its Psychometric Properties}

\section{Öz}

$\mathrm{Bu}$ araştırmanın amacı spor alanında öğrenim gören öğrencilerde spora bağlı olarak gözlenen tükenmişliğin incelenmesi amaciyla geliştirilen Spor Tükenmişliği Envanterini Türkçe'ye uyarlamaktır. Bu amaçla Sorkkila, Ryba, Aunola, Selänne ve Salmela-Aro (2017) tarafindan geliştirilen 10 madde ve üç alt boyuttan oluşan Spor Tükenmişliği Envanteri Türkçe'ye uyarlanarak, geçerlik ve güvenirlik çalışması gerçekleştirilmiştir. Araştırma verileri beden eğitimi ve spor alanında öğrenim gören 250 (98 kadın \%39.2, 152 erkek \%60.8) üniversite öğrencisinden toplanmıştır. Envanterin yapı geçerliği DFA işlemi ile test edilmiş ve modelin geçerliği uyum indeksleri ile değerlendirilmiştir. Envanter için hesaplanan uyum iyiliği katsayıları ise $\chi^{2} / \mathrm{Sd}=3.21$; RMSEA $=.094$; $\mathrm{GFI}=.91$; $\mathrm{AGFI}=.84$; $\mathrm{CFI}=.95, \mathrm{IFI}=.95 ; \mathrm{NFI}=.92$ ve NNFI= .92 olarak hesaplanmıştır. Ayrıca ölçme aracının uyum geçerliği ve ayırt edici geçerlik çalışmaları gerçekleştirilmiştir. Uyum geçerliği kapsamında Beck Depresyon Envanteri ile Spor Tükenmişliği Envanteri arasındaki ilişki hesaplanmıştır. Ayırt edici geçerlik çalışması kapsamında ise Rosenberg Özsaygı Ölçeği ile Spor Tükenmişliği Envanteri arasındaki ilişki incelenmiştir. Ayrıca envanterin güvenirlik düzeyinin belirlenmesi için Cronbach alfa iç tutarlılık katsayısı hesaplanmış, Cronbach alfa iç tutarlılık katsayısının ölçme aracının tümü için 0.81, Tükenme boyutu için 0.61, Duyarsızlaşma boyutu için 0.69 ve Yetersizlik boyutu için 0.61 olduğu görülmüştür. Spor Tükenmişliği Envanteri’nin spor alanında öğrenim gören üniversite öğrencilerinin spor tükenmişliği düzeylerini ölçmede geçerli ve güvenilir bir ölçme arac1 olduğu söylenebilir. Araştırmadan elde edilen bulgular ilgili alanyazın 1şığında tartışılarak uygulayıcılara, gelecekteki araştırmacılara ve ruh sağlığı alanına ilişkin öneriler sıralanmıştır.

Anahtar Kelimeler: Tükenmişlik, Spor Tükenmişliği, Ölçme Aracı Uyarlama.

\begin{abstract}
The purpose of this study to make an adaptation of Sport Burnout Inventory to the Turkish culture which is developed in order to examine the burnout of students studying in sport sciences. For this purpose, Sport Burnout Inventory developed by Sorkkila, Ryba, Aunola, Selänne \& Salmela-Aro (2017) which consists of 10 items and three sub-dimensions has been adapted to Turkish and validity and reliability studies have been done. Data gathered from 250 university students (98 of them $39.2 \%$ are women and 152 of them $60.8 \%$ are men) studying in physical education and sports. The construct validity of the inventory was tested by CFA and the validity of the model was evaluated with fit indices. The goodness of fit indices calculated for the inventory are $\chi 2 / \mathrm{df}=3.21$; RMSEA $=.094$; GFI= $.91 ; \mathrm{AGFI}=.84 ; \mathrm{CFI}=.95, \mathrm{IFI}=.95 ; \mathrm{NFI}=.92$ and $\mathrm{NNFI}=.92$ respectively. Convergent validity and discriminant validity studies of the instrument were also done by using Beck Depression Inventory and Rosenberg Self-Esteem Scale with calculating relationships between for each. In addition, Cronbach alpha internal consistency coefficient was calculated to determine the reliability level of the inventory and it is found 0.81 for overall score, 0.61 for exhaustion, 0.69 for cynicism and 0.61 for inadequacy sub-dimensions. It can be said that SBI is a valid and reliable measurement tool to measure the levels of sports burnout of university students studying in the field of sports. The findings were discussed in the light of the related literature and suggestions were made to the practitioners, future researchers and the field of mental health.
\end{abstract}

Keywords: Burnout, Sport Burnout, Scale Adaptation.

\footnotetext{
* Bu çalışmanın ilk sonuçları 3- 5 Mayıs 2018 tarihleri arasında Muş’ta düzenlenen Uluslararası STEM ve Eğitim Bilimleri Kongresi'nde sözlü bildiri olarak sunulmuştur.

+ Sorumlu yazar: Zekeriya ÇAM, z.cam@alparslan.edu.tr
} 
Çam, Z., Kardaş, F., Eşkisu, M., ve Gelibolu, S. (2019). Spor Tükenmişliği Envanteri’nin Türk kültürüne uyarlanması ve psikometrik özellikleri. CBÜ Beden Eğitimi ve Spor Bilimleri Dergisi, 14(1), 79-96.

\section{GİRIŞ}

İnsanların çalışma yaşamında karşılaştıkları bir problem olan tükenmişlik, Freudenberger (1974) tarafından kavramsallaştırılmış; yorulma, yıpranma, başarısız olma ve aşırı talepler karşısında kişinin enerjisinin bitmesi olarak tanımlanmıştır (Freudenberger, 1975). İlerleyen dönemlerde ise tükenmişlik kavramı fiziksel yorgunluğu içeren (i) duygusal tükenme, yapılan işe ve hizmet alan kişilere yönelik umursamaz ve ilgisiz davranmayı içeren (ii) duyarsızlaşma ve zaman içinde kişinin yaptığı işe yönelik olumsuz duygularının sonucunda kendisini başarısız olarak değerlendirdiği (iii) düşük kişisel başarı hissi olarak boyutlandırılmıştır (Hobfoll ve Shirom, 2001). Özellikle insanlara yüz yüze hizmet sunulan mesleklerde bu durum yaygın bir biçimde gözlenmektedir. Yapılan mesleğin yanı sıra bir işteki günlük çalışma süresinin de tükenmişliği etkilediği belirtilmektedir (Freudenberger, 1975).

Tükenmişlik probleminin yüz yüze hizmetin sunulduğu mesleklerin yanı sıra işçi sınıfında da gözlendiği görülmüştür (Pines, Aronson ve Kafry 1981). Farklı çalışma grupları ve bağlamlarda araştırılan tükenmişlik kavramı, son yirmi yıldır okul bağlamında da ele alınmaktadır. Okul ve öğrenci bağlamında ele alınan tükenmişlik kavramı, okul veya öğrenci tükenmişliği olarak adlandırılmaktadır (Çam, 2016; Çam, Deniz ve Kurnaz, 2014; Çam ve Ögülmüsş, 2017; 2019). Tıpkı çalışanların işyerinde birtakım talep ve beklentilerle karşı karşıya kalmaları gibi okullarda da öğrenciler başarılı olma, derslere devam etme ve buna benzeyen birçok taleple karşı karşıya kalmaktadırlar. Öğrencilerin bu talepleri ya da beklentileri karşılayamamaları, onlarda bir gerginlik oluşturmaktadır (Salmela-Aro, Kiuru, Leskinen ve Nurmi, 2009). Okul tükenmişliği de çalışan tükenmişliği gibi okul ortamında maruz kalınan akademik strese yönelik bir tepki şeklinde gözlenmektedir. Araştırmacılar çalışan tükenmişliği gibi okul tükenmişliğinin de üç boyutlu bir yap1 olarak gözlendiğini belirtmektedirler. Bu boyutlar ise (i) okulda tükenme (exhaustion at school), (ii) okulun anlamına yönelik duyarsizlaşma duygusu (cynicism toward the meaning of school) ve (iii) okulda yetersizlik duygusu (sense of inadequacy at school) olarak siralanmaktadır (Bask ve Salmela-Aro, 2013; Salmela-Aro, Kiuru, Leskinen ve Nurmi, 2009; Yang, 2004). Bu şekilde kavramsallaştırılan ve boyutlandırılan okul tükenmişliğinin yol açtığı sonuçların, çalışanlarda gözlenen tükenmişlik ile benzerlik gösterdiği belirtilmektedir. Bununla beraber çalışanların tükenmişlik düzeyleri ile öğrencilerin okul tükenmişliği düzeyleri ölçme araçlarından alınan puanlar ve tükenmişliğin sonuçları bakımından benzerlik göstermektedir (Pines, Aronson ve Kafry, 1981). 
Akademik bağlamlarda da tartışılmaya başlanan tükenmişlik sorunu sadece akademik eğitim alan öğrencilerde değil, aynı zamanda çeşitli alanlarda mesleki eğitim alan öğrencilerde de gözlenen bir sorundur. Mesleki eğitim alan bu grup içerisinde spor eğitimi alan öğrenciler de bulunmaktadır. Spor alanında eğitim alan öğrenciler, bir yandan akademik gereklilikleri yerine getirirlerken, diğer yandan spor yapmanın getirdiği gereklilikleri de karşılamak zorunda kalmaktadırlar. $\mathrm{Bu}$ durum iki alanda birden başarılı olmayı gerektirdiğinden öğrencilerde tükenmişliğin gözlenmesine neden olabilmektedir. Bunun yanı sıra sporda başarılı olma zorunluluğunun getirdiği baskı ve yarışma durumları spor alanında öğrenim gören öğrencilerin hem okul tükenmişliği hem de spor tükenmişliğine karşı daha kırılgan olmalarına neden olmaktadır (Aunola, Sorkkila, Viljaranta, Tolvanen ve Ryba, 2018).

Açıklamalardan da anlaşılacağı üzere geçmişte iş yaşamı için kavramsallaştırılan tükenmişlik sorunu, sonrasında okul ve öğrenci bağlamına taşınmıştır. Ancak son zamanlarda bu kavram spor alanlarında ve sporcular bağlamında incelenmektedir. Tıpkı okul tükenmişliğinde olduğu gibi spor tükenmişliği, bilişsel-duygusal bir problem olarak değerlendirilmektedir. $\mathrm{Bu}$ kavram, duygusal ve fiziksel tükenmenin bir bileşimi olarak, başarma hissinin azalması ve uğraşılan spor dalına değer atfetmeme olarak tanımlanmaktadır. Duygusal ve fiziksel tükenme, yarışma veya karşılaşmalarda sporcunun sahip olduğu duygusal ve fiziksel kaynaklarının bitmesi olarak karakterize edilmektedir. Başarma hissinin azalması, kişinin kendi spor yeteneğini olumsuz olarak değerlendirmesi ve spordaki başarısının düşmesi olarak tanımlanmaktadır. Son olarak spora verilen değerin azalması ise spora katılım konusunda isteksiz ve alaycı davranma olarak ifade edilmektedir. Ancak sporcu tükenmişliğinin en temel bileşeninin ise duygusal veya fiziksel tükenme olduğu vurgulanmaktadır (Gustafsson, DeFreese ve Madigan, 2017).

Spor ve sporcu tükenmişliği konusunda alanyazında çeşitli modeller ve bu modellerin yanı sıra kuramsal açıklamalar yer almaktadır. Bu modeller arasında en çok kabul gören model ise Smith (1986) tarafından öne sürülen Bilişsel-Duygulanımsal Stres Modeli'dir. Bu modele göre tükenmişlik stres temelli süreçlerle gelişmekte ve kişilik ile motivasyonel faktörlerden ise etkilenmektedir. Örneğin, sporculardan beklenen yoğun antrenman yapma talebi ya da aşırı başarı beklentisi sporcuları tükenmişliğe hazırlayan nedenlerden biridir. Bu tür beklentiler ve talepler karşısında sporcular yetenekleri ölçüsünde bilişsel değerlendirmelerde bulunurlar. Sporcuların yetenekleri ile kendilerinden beklentiler ve değerlerin örtüşmediği durumlarda ise fizyolojik ya da 
Çam, Z., Kardaş, F., Eşkisu, M., ve Gelibolu, S. (2019). Spor Tükenmişliği Envanteri'nin Türk kültürüne uyarlanmas1 ve psikometrik özellikleri. CBÜ Beden Eğitimi ve Spor Bilimleri Dergisi, 14(1), 79-96.

psikolojik tepkiler ortaya çımaktadır. İşte bu tür psikolojik tepkilerden biri de tükenmişliktir (Smith, 1986).

Spor tükenmişliği sporcularda depresif duygu durumuna, strese ve sonunda da sporcunun sporu bırakmasına ya da spordan geri çekilmesine yol açmaktadır. Ancak, uyumlu bir şekilde stresle başa çıma becerileri, umut, algılanan kontrol ve iyimserlik gibi özellikler ise spor tükenmişliğinin daha az gözlendiği bireylerin özellikleri arasında sıralanmaktadır (Gustafsson, Hassmén, Kenttä, Johansson, 2008; Gustafsson ve Skoog, 2012; Raedeke ve Smith, 2004). Bununla beraber özellikle elit sporculardan kendilerini uzun süreli olarak yaptıkları spora adamaları ve yaptıkları sporda başarılı olmaları beklenmektedir. Bu durum beraberinde bazı riskleri de getirmektedir. Bu riskler arasında depresyon, yeme bozuklukları ve tükenmişlik yer almaktadır (Gustafsson, Martinent, Isoard-Gautheur, Hassmén ve Guillet-Descas, 2018).

Alanyazında, çalışanlarda tükenmişlik düzeyini ölçmek üzere çeşitli ölçme araçları bulunmaktadır. Bu çalışmanın içeriği ve kapsamı gereği çalışanların mesleki tükenmişliklerini ölçmek üzere geliştirilen ya da uyarlanan ölçme araçlarına değinilmemiştir. Bununla beraber okul ve öğrenci tükenmişliğini ölçmek üzere geliştirilen ölçme araçları da mevcuttur. Bu ölçme araçları; Aypay (2011) tarafından ortaokul öğrencileri için geliştirilen “İlköğretim II. Kademe Öğrencileri İçin Okul Tükenmişliği Ölçeği”, yine Aypay (2012) tarafından geliştirilen "Ortaöğretim Öğrencileri İçin Okul Tükenmişliği Ölçeği”, Salmela-Aro, Kiuru, Leskinen ve Nurmi (2009) tarafindan ergenler için geliştirilen ve farklı araştırmacılar (Çam ve Ögülmüş, 2017; Seçer, Halmatov, Veyis ve Ateş, 2013) tarafından Türkçe'ye uyarlanan "Okul Tükenmişlik Envanteri” ve son olarak Schaufeli, Martinez, Pinto, Salanova ve Bakker (2002) tarafindan üniversite öğrencileri için geliştirilen ve Çapri, Gündüz ve Gökçakan (2011) tarafından Türkçe uyarlaması gerçekleştirilen "Maslach Tükenmişlik Envanteri Öğrenci Formu (MTE-ÖF)"dur. Alanyazında okul ve öğrenci tükenmişliğini belirlemek üzere geliştirilen veya uyarlanan ölçme araçlarına rastlanırken, sporcu tükenmişliğini belirlemek üzere geliştirilen ya da uyarlanan sınırlı sayıda ölçme aracına rastlanmıştır.

İlgili alanyazın incelendiğinde spor ve sporcu tükenmişliğini ölçmek için geliştirilmiş ölçme araçlarına rastlanmaktadır. Bu ölçme araçlarından biri Raedeke ve Smith (2001) tarafından geliştirilen Sporcu Tükenmişliği Ölçeği' dir (Athlete Burnout Questionnaire/ABQ). Bu ölçek her biri beş maddeden oluşan toplamda üç boyutlu ve 15 maddeli bir ölçme aracıdır. Bu boyutlar ise 
Çam, Z., Kardaş, F., Eşkisu, M., ve Gelibolu, S. (2019). Spor Tükenmişliği Envanteri'nin Türk kültürüne uyarlanmas1 ve psikometrik özellikleri. CBÜ Beden Eğitimi ve Spor Bilimleri Dergisi, 14(1), 79-96.

(i) spor başarısının azalma duygusu, (ii) duygusal ve fiziksel tükenme ile (iii) spora yönelik duyarsızlaşma boyutlarıdır. Bu ölçek 5'li Likert türünde bir ölçektir ve 1= Hiçbir zaman ve 5= Her zaman şeklinde puanlanmaktadır. Ölçme aracından alınan yüksek puanlar sporcularda tükenmişliğin yüksek olduğuna işaret etmektedir. Bu ölçme aracının özgün dildeki formu için hesaplanan Cronbach alfa iç tutarlılık katsayısı spor başarısının azalması duygusu boyutu için .84, duygusal ve fiziksel tükenme boyutu için .88 ve spora yönelik duyarsızlaşma boyutu için ise .87 olarak bulunmuştur. Raedeke ve Smith (2001) tarafından geliştirilen bu ölçek, Kelecek, Kara, Kazak Çetinkalp ve Aşçı (2016) tarafından Türkçe'ye uyarlanmıştır. Ölçeğin uyarlama çalışması Ankara'da lisanslı olarak spor yapan 250 profesyonel sporcu ile gerçekleştirilmiştir. Ölçeğin Türkçe formu doğrulayıcı faktör analizi ile analiz edilmiş ve ölçekte yer alan iki maddenin standardize edilmemiş faktör yüklerinin ( $\lambda$ ) .30'un ve $R^{2}$ (açıklanan varyans) değerlerinin .20 'nin altında olduğu görülmüştür. Bu nedenle ölçekte yer alan iki madde ölçme aracından çıkartılmıştır. Sonuç olarak ölçme aracının Türkçe formu özgün dildeki formdan farklı olarak 13 maddeden oluşmuştur. Bu maddeler ise boyutlara, Duygusal/Fiziksel Tükenme 5 madde, Azalan Başarı Hissi 4 madde ve Duyarsızlaşma 4 madde şeklinde dağılmıştır. Ölçme aracına ait Cronbach alfa iç tutarlılık katsayıları ise Duygusal/Fiziksel Tükenme boyutu için .87, Azalan Başarı Hissi boyutu için .75 ve Duyarsızlaşma boyutu için ise .83 olarak hesaplanmıştır. Bu ölçek aynı zamanda Yıldız (2015) tarafindan da Türkçeye uyarlanmıştır. Ölçek profesyonel futbolcuların spor tükenmişlikleri ile zorbalık düzeyleri arasındaki ilişkinin incelendiği araştırmada kullanılmıştır. Adı geçen araştırmanın verileri 102 profesyonel futbolcudan toplanmıştır. Araştırmadan elde edilen sonuçlara göre ölçeğin Cronbach alfa iç tutarlılık katsayısının .748 ile .807 arasında değiştiği ve ölçeğe ait uyum indekslerinin ise $\mathrm{CFI}=.93$, GFI $=.93, \mathrm{AGFI}=.90, \mathrm{NFI}=.96$ ve $\mathrm{RMSEA}$ için .02 olduğu görülmüştür.

Gerçekleştirilen alanyazın taramasında Sporcu Tükenmişliği Ölçeği (Kelecek, Kara, Kazak Çetinkalp ve Aşçı, 2016) dışında Türkiye'de spor alanında öğrenim gören öğrencilerin spordan tükenme düzeylerini belirlemek için geliştirilen ya da uyarlanan ölçme araçlarına rastlanmamıştır. Ancak bu ölçeğin belirli bir alanda lisanslı spor yapan profesyonel sporculara yönelik olarak uyarlanmış olması ve ölçekte yer alan iki maddenin ölçme aracından çıartılması gibi nedenler bu konuda bir ölçme aracı ihtiyacı olduğunun işareti olarak değerlendirilebilir. Türkiye'de spor alanında belirtilen bu ihtiyaçtan hareketle bu araştırmada spor alanında öğrenim gören öğrencilerin spordan tükenme düzeylerini belirlemek amacıyla kısa, amaca hizmet eden, geçerli ve güvenilir 
Çam, Z., Kardaş, F., Eşkisu, M., ve Gelibolu, S. (2019). Spor Tükenmişliği Envanteri'nin Türk kültürüne uyarlanmas1 ve psikometrik özellikleri. CBÜ Beden Eğitimi ve Spor Bilimleri Dergisi, 14(1), 79-96.

bir ölçme aracının Türk kültürüne uyarlanması amaçlanmıştır. Özetle, bu araştırmanın amacı Sorkkila, Ryba, Aunola, Selänne ve Salmela-Aro (2017) tarafından geliştirilen Spor Tükenmişliği Envanteri'ni (Sports Burnout Inventory) Türk kültürüne uyarlayarak, geçerlik ve güvenirlik değerlerini belirlemektir.

\section{YÖNTEM}

\section{Araştırma Modeli}

Bu araştırmada Spor Tükenmişliği Envanteri’nin Türkçe formunun psikometrik özellikleri incelenmiştir. Bu nedenle çalışma var olan bir durumu ortaya koymaktadır. Alanyazında bu tür araştırmalar, tarama modelleri kapsamında ele alınmaktadır (Karasar, 2011).

\section{Çalışma Grubu}

Araştırmanın çalışma grubunu 2017-2018 öğretim yılı bahar döneminde Türkiye'deki üç devlet üniversitesinin Beden Eğitimi ve Spor lisans programlarında öğrenim görmekte olan 250 öğrenci oluşturmuştur. Katılımcıların 98'i (\%39.2) kadın ve 152'si (\%60.8) erkek öğrencilerden oluşmaktadır. Katılımcıların yaş ortalaması $\bar{X}=22.15$, standart sapması ise $S=3.17^{\prime}$ dir.

\section{Veri Toplama Araçları}

Spor Tükenmişliği Envanteri (Sport Burnout Inventory): Spor Tükenmişliği Envanteri (STE), Salmela-Aro ve ark., (2009) tarafindan öğrencilerin okul tükenmişlik düzeylerini belirlemek için geliştirilen Okul Tükenmişlik Envanteri'nde yer alan maddelerin spor alanına uyarlanması ile Sorkkila ve ark., (2017) tarafindan geliştirilmiştir. Envanter toplamda 10 madde ve üç alt boyuttan oluşmaktadır. Envanterde yer alan boyutlar (i) Spordan Tükenme (exhaustion from one's sport), (ii) Sporun Anlamına Yönelik Duyarsızlaşma (cynicism toward the meaning of one's sport) ve (iii) Sporcu Yetersizliği (feelings of inadequacy as an athlete) olarak adlandırılmıştır. Ancak bu araştırmada bu boyutlar kısaca (i) Tükenme, (ii) Duyarsızlaşma ve (iii) Yetersizlik olarak kullanılmıştır. Envanterin puanlanması 5'li Likert olarak yapılmaktadır. Puanlama aralıkları 1= Kesinlikle katılmıyorum, 2= Katılmıorum, 3= Kararsızım, 4= Katıliyorum ve 5= Tamamen Katılıyorum şeklindedir. Envanterden alınan yüksek puan katılımcılarda spor tükenmişliğinin yoğun yaşandığının bir işareti olarak değerlendirilmektedir. Envanterin geliştirilmesi çalışmasında 
geçerlik ve güvenirlik analizleri için Finlandiyalı ergenlerden oluşan 391 spor okulu öğrencisinden veri toplanmıştır. Ölçme aracının geçerlik çalışmaları kapsamında gerçekleştirilen Doğrulayıcı Faktör Analizi işleminden elde edilen uyum indeksleri ise $\chi^{2}(61)=137.85, p<.001$; CFI $=0.94$; TLI $(\mathrm{NNFI})=0.91$; RMSEA $=0.06$ olarak hesaplanmıştır. Ölçme aracının güvenirlik analizleri kapsamında Cronbach alfa $(\alpha)$ iç tutarlılık katsayısı incelenmiştir. Elde edilen iç tutarlılık katsayıları ise tüm envanter için 0.90; Tükenme boyutu için 0.90; Duyarsızlaşma boyutu için 0.92 ve Yetersizlik boyutu için 0.91 olarak hesaplanmıştır.

Beck Depresyon Envanteri (BDE): Beck Depresyon Envanteri, Spor Tükenmişliği Ölçeği'inin uyum geçerliğinin (concurrent validity) belirlenmesi için kullanılmıştır. Beck Depresyon Envanteri bireylerde depresyon düzeyinin belirlenmesi amacıyla geliştirilmiş ve 21 maddeden oluşan bir ölçme aracıdır. BDE 0-3 arasında puanlanmakta ve her bir soruda bireylerin son bir hafta içindeki ruhsal durumlarını belirtmeleri istenen ifadeler yer almaktadır. Ölçme aracından alınan en düşük puan 0 , en yüksek puan ise 63'tür. BDE'nin özgün dildeki güvenirlik katsayısı Spearman-Brown iki yarı güvenirlik yöntemi ile incelenmiş ve bu değerin 0.93 olduğu görülmüştür (Beck, Ward, Mendelson, Mock ve Erbaugh, 1961). BDE'nin Türkçe formunun geçerlik ve güvenirlik çalışmaları Hisli (1989) tarafından yapılmıştır. Hisli (1989) tarafından yapılan çalışmada BDE’nin Cronbach alfa iç tutarlılık katsayısı 0.80, Spearman-Brown tekniği ile hesaplanan iki yarı güvenirliği ise 0.74 olarak hesaplanmıştır. Bu araştırmada ise BDE’nin Cronbach alfa iç tutarlılık katsayısı 0.89 olarak hesaplanmıştır. Elde edilen bu değere dayalı olarak BDE'nin depresyonu ölçmede geçerli ve güvenilir bir ölçme aracı olduğu söylenebilir.

Rosenberg Özsaygı Öıçeği (RSÖ): Rosenberg Özsaygı Ölçeği, Spor Tükenmişliği Envanteri’nin ayırt edici geçerlik (discriminant validity) çalışması kapsamında kullanılmıştır. Toplamda 10 maddeden oluşan bu ölçek Rosenberg (1965) tarafından kişilerin özsaygılarını ölçmek üzere geliştirilmiş 4'lü Likert ( $1=$ Hiç katılmıyorum- 4= Tamamen Katılıyorum) türü bir ölçme aracıdır. Ölçekteki 3, 5, 8, 9 ve 10. maddeler ters puanlanmaktadır. Ölçekten alınan yüksek puanlar bireylerin yüksek özsaygıya sahip olduklarını göstermektedir. Ölçme aracının özgün dildeki geçerlik ve güvenirlik çalışmasında Cronbach alfa iç tutarlılık katsayısının 0.77 ile 0.88 arasında değiştiği gözlenmiştir. Ölçeğin Türkçeye uyarlama, geçerlik ve güvenirlik çalışması Çuhadaroğlu (1986) tarafından gerçekleştirilmiştir. Türkçeye uyarlama çalışmasında ise gerçekleştirilen test- 
Çam, Z., Kardaş, F., Eşkisu, M., ve Gelibolu, S. (2019). Spor Tükenmişliği Envanteri'nin Türk kültürüne uyarlanmas1 ve psikometrik özellikleri. CBÜ Beden Eğitimi ve Spor Bilimleri Dergisi, 14(1), 79-96.

tekrar test güvenirlik katsayısının ise 0.48 ile 0.79 arasında olduğu belirtilmektedir. Bu araştırmada hesaplanan Cronbach alfa iç tutarlılık katsayısının ise 0.90 olduğu görülmüştür.

\section{Verilerin Analizi}

Araştırmadan elde edilen veriler istatistik paket programları yardımıyla analiz edilmiştir. Verilerin analizinde betimsel istatistikler, Doğrulayıcı Faktör Analizi (DFA), madde analizi ve korelasyon analizi işlemleri gerçekleştirilmiştir. Katılımcıların ölçme araçlarından aldıkları puanların dağılımları aritmetik ortalama, standart sapma, çarpıklık ve basıklık değerleri gibi betimsel istatistiklerle incelenmiştir. Ölçme aracının özgün dildeki faktör yapısının Türk kültüründe de doğrulanıp doğrulanmadığının belirlenmesi için DFA işlemi gerçekleştirilmiştir. DFA işleminde ölçme aracının geliştirilmesi çalışmasında olduğu gibi sağlam en çok olabilirlik (robust maximum likelihood) tekniği tercih edilmiştir. DFA işlemi sonucunda ölçme aracının mevcut yapısının doğrulanıp doğrulanmadığı model uyum indeksleri ile incelenmiş, bu indekslerden $\chi^{2} / \mathrm{Sd}$, RMSEA, GFI, AGFI, CFI, IFI, NFI ve NNFI gibi uyum indekslerine bakılmıştır. Ölçme aracının uyum ve ayırt edici geçerliğinin belirlenmesi için Pearson Momentler Çarpımı Korelasyon Katsayısı hesaplanmıştır. Ölçme aracının güvenirlik analizleri kapsamında iç tutarlılık katsayısının belirlenmesi için Cronbach alfa iç tutarlılık katsayısı hesaplanmıştır. Son olarak ölçme aracının madde-toplam korelasyonları hesaplanarak madde analizi işlemi gerçekleştirilmiştir.

\section{BULGULAR}

\section{Spor Tükenmişliği Envanteri’nin Türk Kültürüne Uyarlanma Çalışması}

Spor Tükenmişliği Envanteri (STE) Türk kültürüne uyarlanmadan önce ölçme aracını geliştiren araştırmacılardan uyarlama izinleri alınmıştır. Yazarlardan alınan izinlerin ardından ölçme aracının uyarlama işlemine geçilmiştir. STE başlangıçta iyi düzeyde İngilizce bilen ve doktora derecesini almış araştırmacılar tarafından özgün dilden (İngilizce), Türkçeye çevrilmiştir. Ölçme aracının araştırmacılar tarafından çevrilen hali Beden Eğitimi ve Spor ile Eğitim Bilimleri alanında doktora derecesine sahip ve İngilizceye de hâkim öğretim üyeleri tarafından incelenmiştir. Alan uzmanlarından gelen görüşlerle düzenlenen STE'ye son hali verilmiş ve uygulama aşamasına geçilmiştir. 
Çam, Z., Kardaş, F., Eşkisu, M., ve Gelibolu, S. (2019). Spor Tükenmişliği Envanteri'nin Türk kültürüne uyarlanmas1 ve psikometrik özellikleri. CBÜ Beden Eğitimi ve Spor Bilimleri Dergisi, 14(1), 79-96.

\section{Betimsel Analizlere ait Bulgular}

Araştırmaya katılan 250 üniversite öğrencisinden elde edilen veri seti için öncelikle betimsel istatistikler hesaplanmıştır. $\mathrm{Bu}$ analizlerde ölçme aracına ait puan dağılımları incelenmiştir. Betimsel istatistiklere ait bulgular Tablo 1'de sunulmuştur.

Tablo 1. Araştırmada ele alınan değişkenlere ait betimsel istatistikler

\begin{tabular}{lccrrrr}
\hline Değisşkenler & Min. & Maks. & \multicolumn{1}{c}{$\overline{\boldsymbol{X}}$} & $\mathbf{S}_{\mathbf{x}}$ & Çarpıklık & Basıklık \\
\hline Tükenme & 4.00 & 23.00 & 10.09 & 3.64 & .528 & .085 \\
Duyarsızlaşma & 3.00 & 15.00 & 5.34 & 2.35 & 1.122 & 1.071 \\
Yetersizlik & 3.00 & 15.00 & 7.17 & 2.82 & .428 & -.421 \\
Özsaygi & 10.00 & 40.00 & 22.06 & 8.23 & .521 & -.916 \\
Depresyon & .00 & 60.00 & 10.84 & 9.93 & 1.593 & 3.420 \\
STE Toplam Puan & 10.00 & 47.00 & 22.61 & 7.42 & .454 & -.016 \\
\hline
\end{tabular}

Tablo 1'de yer alan betimsel istatistikler incelendiğinde ölçme araçlarından alınan puanların dağılımı gözlenmektedir. Tabloda yer alan çarpıklık ve basıklık değerleri veri setine ait dağılımın normallik koşulunu sağlayıp sağlamadığına ilişkin bir bilgi sunmaktadır. Çarpıklık ve basıklık değerlerinin -1.5 ile +1.5 değerleri arasında olması, veri setine ait dağılımın normal dağılım gösterdiği biçiminde yorumlanmaktadır (Pituch ve Stevens, 2016: 283). Ancak tabloda depresyon puanlarına ait çarpıklık ve basıklık değerlerinin bu sınır değerleri aştığı gözlenmiş̧tir. $\mathrm{Bu}$ nedenle depresyon değişkenine ait verilere karesel dönüştürme işlemi uygulanarak çarpıklık ve basıklık değerleri hesaplanmış (Çarpıklık= .120; Basıklık= -.073) ve veri setine ait dağılımın normal dağılım koşulunu sağladığı görülmüştür.

\section{STE’nin Geçerlik Çalışmalarına Ait Bulgular}

STE'nin yapı geçerliğinin test edilmesi amacıyla istatistik paket programı yardımıyla DFA işlemi gerçekleştirilmiştir. Araştırmaya katılan 250 katılımcıdan elde edilen veriler için gerçekleştirilen DFA işleminden elde edilen sonuçlar, ölçme aracına ait faktör yükleri, güvenirlik katsayıları ve düzeltilmiş madde-toplam korelasyon değerleri Tablo 2'de özetlenmiş̧tir. Ayrıca istatistik paket programından elde edilen şekil Ek-2'de sunulmuştur. 
Çam, Z., Kardaş, F., Eşkisu, M., ve Gelibolu, S. (2019). Spor Tükenmişliği Envanteri'nin Türk kültürüne uyarlanmas1 ve psikometrik özellikleri. CBÜ Beden Eğitimi ve Spor Bilimleri Dergisi, 14(1), 79-96.

Tablo 2. STE’ye ait faktör yükü, güvenirlik ve madde toplam korelasyonu katsayıları

\begin{tabular}{llcccccc}
\hline Boyutlar & Maddeler & $\mathbf{R}_{\mathbf{i j}}$ & $\boldsymbol{\lambda}$ & $\boldsymbol{\beta}$ & $\mathbf{t}$ & $\mathbf{R}^{\mathbf{2}}$ & $\boldsymbol{\alpha}$ \\
\hline \multirow{4}{*}{ Tükenme } & S1 & .548 & .73 & .71 & $13.20^{* * *}$ & .50 & \\
& $\mathbf{S 4}$ & .386 & .73 & .74 & $13.18^{* * *}$ & .55 & .61 \\
& S8 & .409 & .55 & .55 & $7.80^{* * *}$ & .30 & \\
\hline \multirow{3}{*}{ Duyarsızlaşma } & S10 & .527 & .52 & .44 & $6.48^{* *}$ & .20 & .69 \\
& S2 & .557 & .83 & .75 & $14.14^{* * *}$ & .57 & \\
\hline \multirow{3}{*}{ Yetersizlik } & S5 & .666 & .44 & .48 & $6.95^{* *}$ & .23 & .61 \\
& S6 & .402 & .69 & .54 & $9.06^{* * *}$ & .29 & \\
\hline
\end{tabular}

Tüm Envanter $\quad .81$

Not: $\boldsymbol{R}_{i j}$ : Düzeltilmiş madde-toplam korelasyonları; $\lambda$ : Standardize edilmemiş faktör yükleri; $\boldsymbol{\beta}$ : Standardize edilmiş faktör yükleri; $\boldsymbol{R}^{2}$ : Maddelerin açıkladığı varyans; ${ }^{*} \mathrm{p}<.05 ;{ }^{* *} \mathrm{p}<.01$

Tablo 2'de yer alan değerler incelendiğinde STE'de yer alan maddelerin madde toplam korelasyonu katsayılarının $\left(R_{i j}\right) .39$ ile .67 arasında değiştiği, DFA işlemi sonucunda elde edilen standardize edilmiş faktör yüklerinin $(\beta) .44$ ile .75 arasında değiştiği ve her bir maddenin açıkladığı varyansın $\left(R^{2}\right) .20$ ile .57 arasında değiştiği gözlenmektedir. Ayrıca DFA işlemi sonucunda STE’nin özgün dildeki üç faktörlü yapısının doğrulanıp doğrulanmadığına yönelik gerçekleştirilen analizlerde üç faktörlü yapının doğrulandığı gözlenmiştir. Bu kapsamda hesaplanan model uyum iyiliği indeksleri ise $\chi^{2} / \mathrm{Sd}=3.21$; RMSEA= .094; GFI= .91; AGFI= .84; $\mathrm{CFI}=.95, \mathrm{IFI}=.95 ; \mathrm{NFI}=.92$ ve $\mathrm{NNFI}=.92$ olarak bulunmuştur.

DFA işlemi ile yapı geçerliği test edildikten sonra STE’nin uyum geçerliği kapsamında Beck Depresyon Envanteri (BDE) ile STE toplam puan arasındaki ilişki incelenmiştir. STE ile BDE arasındaki ilişkinin incelenmesi için Pearson Momentler Çarpımı Korelasyon Katsayısı ( $r$ ) hesaplanmıştır. Yapılan analizlerde STE ile BDE arasında $r=.32 ; p<.01$ düzeyinde bir ilişki olduğu tespit edilmiştir. Bunun yanı sıra STE’nin ayırt edici geçerlik çalışmaları kapsamında ise Rosenberg Özsaygı Ölçeği (RSÖ) ile arasındaki ilişki incelenmiştir. Yapılan analizlerde STE ile RSÖ arasında $r=-.03 ; p>.05$ düzeyinde bir ilişki olduğu gözlenmiştir. Bulgular incelendiğinde STE ile BDE arasında düşük düzeyde, pozitif ve istatistiksel açıdan manidar bir ilişki olduğu ( $r=$ $.30 ; p<.01)$, ancak RSÖ ile arasında ise istatistiksel açıdan manidar bir ilişki olmadığı görülmüştür $(r=-.03 ; p>.05)$. 
Çam, Z., Kardaş, F., Eşkisu, M., ve Gelibolu, S. (2019). Spor Tükenmişliği Envanteri’nin Türk kültürüne uyarlanması ve psikometrik özellikleri. CBÜ Beden Eğitimi ve Spor Bilimleri Dergisi, 14(1), 79-96.

\section{STE’nin Güvenirlik Çalışmalarına Ait Bulgular}

Doğrulayıcı faktör analizi işlemi ile ölçme aracının faktör yapısı test edildikten sonra ölçme aracının güvenirlik düzeyi incelenmiştir. Bu kapsamda ölçme aracına ait iç tutarlılık katsayısı Cronbach alfa iç tutarlılık katsayısı ile değerlendirilmiştir. Üç alt boyut ve toplam on maddeden oluşan STE’nin tümü için hesaplanan alfa iç tutarlılık katsayısının .81 olduğu gözlenmiştir. Ayrıca alt boyutlar için hesaplanan Cronbach alfa iç tutarlılık katsayılarının ise Tükenme boyutu için .61, Duyarsızlaşma boyutu için .69 ve Yetersizlik boyutu için .61 olduğu görülmüştür.

\section{TARTIŞMA, SONUÇ ve ÖNERILLER}

$\mathrm{Bu}$ araştırmada Sorkkila ve ark., (2017) tarafindan geliştirilen Spor Tükenmişliği Envanteri'nin (STE) Türkçe formunun psikometrik özellikleri incelenmiştir. Beden eğitimi ve spor eğitimi alanında öğrenim gören 250 katılımcıdan elde edilen veriler üzerinde gerçekleştirilen analizlerde STE'nin yap1 geçerliği test edilmiştir. Gerçekleştirilen doğrulayıcı faktör analizi işleminden elde edilen uyum indeksi değerleri ise $\chi^{2} / \mathrm{Sd}=3.21$; RMSEA $=.094$; $\mathrm{GFI}=.91$; AGFI= $.84 ; \mathrm{CFI}=.95, \mathrm{IFI}=.95 ; \mathrm{NFI}=.92$ ve $\mathrm{NNFI}=.92$ olarak hesaplanmıştır. Sorkkila ve ark., (2017) tarafından gerçekleştirilen analizlerde ölçme aracının özgün dildeki formu için bu değerler $\chi^{2}{ }_{(32)}=$ 80.22, $p<0.001 ; \mathrm{CFI}=0.95$; TLI $(\mathrm{NNFI})=0.93, \mathrm{RMSEA}=0.06$ olarak hesaplanmıştır. Ölçme aracının özgün dildeki uyum indeksleri ile bu araştırmada hesaplanan uyum indekslerinin birbirlerine oldukça yakın değerler aldıkları gözlenmiştir. Bunun yanı sıra ölçme araçlarının faktör yapılarının test edilmesinde sıklıkla başvurulan uyum indeksi değerleri alanyazında Tablo 3 'te yer alan ölçütlere göre değerlendirilmektedir (Çokluk, Şekercioğlu ve Büyüköztürk, 2010; Schermelleh-Engel, Moosbrugger ve Müller 2003; Sümer, 2000).

Tablo 3. Model Uyum İndeksi Değerlendirme Ölçütleri

\begin{tabular}{lcc}
\hline Uyum İndeksleri & İyi Uyum & Kabul Edilebilir Uyum \\
\hline$\chi^{2} / \mathrm{Sd}$ & $0.00 \leq \chi^{2} / \mathrm{Sd} \leq 3.00$ & $3.00 \leq \chi^{2} / \mathrm{Sd} \leq 5.00$ \\
$\mathrm{p}$ & $0.05<\mathrm{p} \leq 1.00$ & $0.01 \leq \mathrm{p} \leq 0.05$ \\
RMSEA & $0.00 \leq \mathrm{RMSEA} \leq 0.05$ & $0.05 \leq \mathrm{RMSEA} \leq 0.10$ \\
$\mathrm{NFI}$ & $0.95 \leq \mathrm{NFI} \leq 1.00$ & $0.90 \leq \mathrm{NFI} \leq 0.95$ \\
$\mathrm{NNFI}$ & $0.97 \leq \mathrm{NNFI} \leq 1.00$ & $0.95 \leq \mathrm{NNFI} \leq 0.97$ \\
$\mathrm{CFI}$ & $0.95 \leq \mathrm{CFI} \leq 1.00$ & $0.90 \leq \mathrm{CFI} \leq 0.95$ \\
GFI & $0.95 \leq \mathrm{GFI} \leq 1.00$ & $0.90 \leq \mathrm{GFI} \leq 0.95$ \\
AGFI & $0.90 \leq \mathrm{AGFI} \leq 1.00$ & $0.85 \leq \mathrm{AGFI} \leq 0.90$ \\
\hline
\end{tabular}


Çam, Z., Kardaş, F., Eşkisu, M., ve Gelibolu, S. (2019). Spor Tükenmişliği Envanteri’nin Türk kültürüne uyarlanması ve psikometrik özellikleri. CBÜ Beden Ĕgitimi ve Spor Bilimleri Dergisi, 14(1), 79-96.

Tabloda yer alan ölçüt değerler incelendiğinde STE'nin Türkçe formuna ait doğrulayıcı faktör analizinden elde edilen değerlerin iyi uyuma işaret ettiği söylenebilir. Yine bu çalışmadan elde edilen bulgulara dayalı olarak STE’nin üç faktörlü yapısının Türk kültüründe doğrulandığı söylenebilir. Diğer bir ifade ile STE’nin beden eğitimi ve spor alanında öğrenim gören öğrencilerin spordan tükenme düzeylerini ölçmede geçerli bir ölçme aracı olduğu söylenebilir.

Yapı geçerliği çalışmasının ardından STE‘nin uyum ve ayırt edici geçerlik çalışmaları gerçekleştirilmiştir. Bu kapsamda uyum geçerliği için STE ile Beck Depresyon Envanteri (BDE), ayırt edici geçerliği için ise Rosenberg Özsaygı Ölçeği (RSÖ) arasındaki ilişkiler incelenmiştir. Korelasyon tekniği kullanılarak yapılan analizlerde STE ile BDE arasinda $r=.32 ; p<.01$ düzeyinde, STE ile RSÖ arasında ise $r=-.03 ; p>.05$ düzeyinde bir ilişki olduğu gözlenmiştir. Diğer bir ifade ile depresyon ve spor tükenmişliği arasında düşük düzeyde, pozitif ve istatistiksel açıdan manidar bir ilişki olduğu, spor tükenmişliği ile özsaygı arasında ise istatistiksel açıdan manidar bir ilişki olmadığı söylenebilir. Sorkkila ve ark., (2017) tarafından yapılan çalışmada depresif belirtiler ile spor tükenmişliği toplam puan arasındaki ilişki $r=.13$; p> .05 olarak hesaplanmıştır. Diğer bir ifade ile depresif belirtiler ile spor tükenmişliği arasında istatistiksel açıdan manidar bir ilişki tespit edilmemiştir. Buna karşın özsaygı değişkeni ile spor tükenmişliği arasındaki ilişkinin ise $r=-.39 ; p<.01$ olduğu görülmüştür. Bu araştırmada ise söz konusu araştırmanın tam aksi yönünde bir bulgu elde edilmiştir. Sorkkila ve ark., (2017) depresyon ve spor tükenmişliği toplam puanı arasında manidar bir bulguya ulaşmamalarına karşın, tükenme alt boyutu ile depresyon arasında düşük düzeyde de olsa bir ilişki olduğu sonucuna ulaşmışlardır ( $r=$ $.22 ; p<.05)$. Alanyazında tükenmişliğin ana ve en temel öğesinin tükenme ya da duygusal tükenme olduğu vurgulanmaktadır. Bu nedenle depresif belirtiler ile tükenmişlik arasında kısmen de olsa pozitif bir ilişki olduğu ifade edilmektedir (Salmela-Aro, Savolainen ve Holopainen, 2009). Ancak spor tükenmişliği ile özsaygı değişkeni arasında ise bir ilişki olmadığı görülmüştür ( $r=-.03$; p>.05). Oysaki sporcularla yapılan nitel araştırmalar kapsamında yapılan görüşmelerde performans temelli bir öz-saygı yaklaşımının tükenmişliğe neden olduğu ortaya konulmuştur. Özsaygının bir işte başarılı olma ile eşdeğer tutulduğu durumlarda kişiler performanslarına odaklanmaktadırlar ve olası bir başarısızlık durumunda ise tükenmişlik duygusu yaşamaktadırlar (Gustafsson, Hassmén, Kenttä, Johansson, 2008; Gustafsson, Kenttä, Hassmén, Lundqvist ve Durand-Bush, 2007). Ancak bu araştırmada katılımcıların ne kadarının performansa bağlı bir özsaygı özelliğine sahip olduklarına ilişkin bir veri bulunmamaktadır. Bu durum çalışmanın bir 
Çam, Z., Kardaş, F., Eşkisu, M., ve Gelibolu, S. (2019). Spor Tükenmişliği Envanteri'nin Türk kültürüne uyarlanmas1 ve psikometrik özellikleri. CBÜ Beden Eğitimi ve Spor Bilimleri Dergisi, 14(1), 79-96.

sınırlılığ1 olarak kabul edilebilir. Koşullu özsaygı ya da koşullu öz-değer ile sporcu tükenmişliği arasındaki ilişkiyi inceleyen araştırmaların yapılması konu hakkında daha net birtakım bilgiler sunabilir. Çünkü bu araştırmada yalnızca genel özsaygı değişkeni ile sporcu tükenmişliği arasındaki ilişkiler incelenmiştir. Sorkkila ve ark., (2017) araştırmasından elde edilen bulgu (r= $.39 ; \mathrm{p}<.01)$ ile bu araştırmanın bulgusu arasındaki tutarsızlığın nedenlerinden biri bu durum olabilir. Bununla beraber araştırmanın yapıldığı kültürel bağlamın farklı olması da (FinlandiyaTürkiye) bu bulgunun nedenlerinden biri olarak düşünülebilir.

Yapı geçerliği çalışması ile üç faktörlü yapının doğrulanmasının ardından ölçme aracı için Cronbach alfa iç tutarlılık katsayısı hesaplanarak, ölçme aracının güvenirlik düzeyi belirlenmiştir. Yapılan analizlerde ölçme aracına ait Cronbach alfa değerlerinin tüm envanter için .81, Tükenme boyutu için .61, Duyarsızlaşma boyutu için .69 ve Yetersizlik boyutu için .61 olduğu görülmüştür. Ancak bu değerlerin ölçme aracına ait özgün dildeki güvenirlik değerlerinden düşük olduğu görülmektedir. Sorkkila ve ark., (2017) tarafından yapılan çalışmada ise tüm envanter için hesaplanan Cronbach alfa iç tutarlılık katsayısı .90, Tükenme boyutu için .90, Duyarsızlaşma boyutu için .92 ve Yetersizlik boyutu için .91 olarak hesaplanmıştır. Elde edilen değerlerin farklılaşması iki nedene bağlanabilir. Bunlardan biri çalışmanın farklı kültürel bağlamlarda gerçekleştirilmiş olması, diğeri ise çalışma gruplarının gelişimsel özelliklerinin farklılık göstermesidir. Bireyci kültürün özelliklerini taşıyan Finlandiya ve toplulukçu kültürün özelliklerini taşıyan Türkiye'deki öğrencilerin spordan bıkma ya da tükenme nedenleri farklılık gösterebilir. Özellikle Asya ve Doğu gibi toplulukçu kültürlerde başkalarının kişi hakkındaki değerlendirmeleri önemlidir. Bu nedenle diğerlerinin kişi hakkındaki düşünceleri özellikle yüksek performans sergilemek zorunda olan sporcular için oldukça önem taşıyabilir. Bu nedenle diğerlerinin düşüncelerini önemsemek ve değerlendirmelerini dikkate almak bireylerde başarısızlık korkusuna yol açmakla beraber, bu durum stres ya da tükenmişlik gibi durumların gözlenmesine de neden olabilmektedir (Çam, 2016). Bunun yanı sıra Finlandiya örneğinde gerçekleştirilen geçerlik ve güvenirlik çalışması spor alanında öğrenim gören ergenler ile gerçekleştirilmiş̧ir. Bu araştırma ise spor alanında öğrenim gören üniversite öğrencileri üzerinde yapılmıştır. Elde edilen değerlerin farklılık göstermesinin nedenlerinden biri de bu olabilir. Ancak her ne kadar elde edilen değerler düşük gibi görünse de bu değerlerin ölçme araçlarında aranan ölçüt güvenirlik değerine $(\alpha=.70)$ oldukça yakın olduğu söylenebilir. Her ne kadar üç alt boyut üzerinden bir yapı geçerliği sağlansa da bu üç alt boyut birbirleri ile yakın ve pozitif bir ilişkiye 
sahiptir (Sorkkila ve ark., 2017). Buna ek olarak STE’nin toplam puanının hesaplandığ araştırmalar da mevcuttur (Sorkkila, Aunola ve Ryba, 2017; Sorkkila, Ryba, Selänne ve Aunola, 2018). Tüm envantere ait Cronbach alfa değeri (.81) incelendiğinde bu değerin ölçüt değerden yüksek olduğu söylenebilir. Buna dayalı olarak STE’nin spor alanında öğrenim gören üniversite öğrencilerinin spor tükenmişlik düzeylerini belirlemede geçerli ve güvenilir bir ölçme aracı olduğu söylenebilir. Araştırma ortaya koyduğu bulguların yanı sıra bazı sınırlılıklara da sahiptir. Bu sınırlılıklardan biri ölçme aracı için test-tekrar test güvenirlik katsayısının hesaplanmamasıdır. Farklı örneklemlerde ölçme aracının psikometrik özelliklerinin inceleneceği araştırmalarda testtekrar test güvenirlik katsayısının hesaplanması faydalı olacaktır.

Sonuç olarak 10 madde ve üç boyuttan oluşan STE’nin spor alanında eğitim alan üniversite öğrencilerinin spor tükenmişliği düzeylerinin belirlenmesinde geçerli ve güvenilir bir ölçme aracı olduğu görülmüştür. Bununla beraber spor tükenmişliğinin akademik başarının negatif bir yordayıcısı olduğu söylenebilir. Araştırmadan elde edilen sonuçlara dayalı olarak aşağıda yer alan öneriler sıralanmıştır:

- Spor Tükenmişliği Envanteri (STE) ile sporcu tükenmişliğinin belirlenmesi ve başka değişkenlerle iliş̧isine yönelik araştırmalar yapılabilir.

- STE'den farklı spor alanları ile meşgul olan sporcuların tükenmişlik düzeylerinin belirlenmesinde yararlanılabilir.

- STE’nin faktör yapısı spor alanında öğrenim gören ergenler üzerinde test edilerek ergenler için faktör yapısı test edilebilir.

- Spor tükenmişliği ile okul tükenmişliği arasındaki ilişkiler incelenerek, iki değişkenin birbirlerini nasıl ve ne oranda etkilediğine ilişkin uzun süreli boylamsal araştırmalar yapılabilir.

- Spor tükenmişliğinin önlenmesi ve azaltılmasına yönelik yapılacak psiko-eğitsel grup çalışmalarında STE'den yararlanılabilir. 
Çam, Z., Kardaş, F., Eşkisu, M., ve Gelibolu, S. (2019). Spor Tükenmişliği Envanteri’nin Türk kültürüne uyarlanması ve psikometrik özellikleri. CBÜ Beden Eğitimi ve Spor Bilimleri Dergisi, 14(1), 79-96.

\section{KAYNAKLAR}

Aunola, K., Sorkkila, M., Viljaranta, J., Tolvanen, A., \& Ryba, T. V. (2018). The role of parental affection and psychological control in adolescent athletes' symptoms of school and sport burnout during the transition to upper secondary school. Journal of Adolescence, 69, 140-149.

Aypay, A. (2011). İlköğretim II. kademe öğrencileri için okul tükenmişliği ölçeği: Geçerlik ve güvenirlik çalışması. Kuram ve Uygulamada Ĕ̈itim Bilimleri, 11(2), 511-527.

Aypay, A. (2012). Ortaöğretim öğrencileri için okul tükenmişliği ölçeği (OOTÖ). Kuram ve Uygulamada Eğitim Bilimleri, 12(2), 773-787.

Bask, M., \& Salmela-Aro, K. (2013). Burned out to drop out: Exploring the relationship between school burnout and school dropout. European Journal of Psychology of Education, 28(2), 511-528.

Beck, A. T., Ward, C. H., Mendelson, M., Mock, J., \& Erbaugh, J. (1961). An inventory for measuring depression. Archives of General Psychiatry, 4(6), 561-571.

Çam, Z. (2016). Lise ögrencilerinde okul tükenmişliğine ilişkin bir modelin sınanması ve sınıf tekrarını yordama düzeyinin incelenmesi. Yayımlanmamış doktora tezi, Ankara Üniversitesi, Ankara.

Çam, Z., \& Öğülmüş, S. (2017). Okul Tükenmişlik Envanteri’nin Türkçeye uyarlanması ve psikometrik nitelikleri. Bitlis Eren Üniversitesi Sosyal Bilimler Enstitüsü Dergisi, 6(2), 14-29.

Çam, Z., \& Öğülmüş, S. (2019). Çalışma yaşamından okula: Okul tükenmişliğine kuramsal yaklaşımlar. Psikiyatride Güncel Yaklaşımlar, 11(1), 4-4. Retrieved from http://dergipark.gov.tr/pgy/issue/39299/392556.

Çam, Z., Deniz, K. Z., \& Kurnaz, A. (2014). School burnout: Testing a structural equation model based on percieved social support, perfectionism and stress variables. Eğitim ve Bilim, 39(173), 310-325.

Çapri, B., Gündüz, B., \& Gökçakan, Z. (2011). Maslach tükenmişlik envanteri-öğrenci formu (MTE-ÖF)'nun Türkçe'ye uyarlaması: Geçerlik ve güvenirlik çalışması. Çukurova Üniversitesi Eğitim Fakültesi Dergisi, 40(1), 134-147.

Çokluk, Ö., Şekercioğlu, G., \& Büyüköztürk, Ş. (2010). Sosyal bilimler için çok değişkenli istatistik: SPSS ve LISREL uygulamaları. Ankara: Pegem Yayıncılık.

Çuhadaroğlu, F. (1986). Adolesanlarda benlik saygısı. Yayımlanmamış Tıpta Uzmanlık Tezi, Hacettepe Üniversitesi Tıp Fakültesi Psikiyatri Anabilim Dalı, Ankara.

Freudenberger, H. J. (1974). Staff burn-out. Journal of Social Issues, 30(1), 159-165.

Freudenberger, H. J. (1975). The staff burn-out syndrome in alternative institutions. Psychotherapy: Theory, Research \& Practice, 12(1), 73-82.

Gustafsson, H., \& Skoog, T. (2012). The mediational role of perceived stress in the relation between optimism and burnout in competitive athletes. Anxiety, Stress \& Coping, 25(2), 183-199.

Gustafsson, H., DeFreese, J. D., \& Madigan, D. J. (2017). Athlete burnout: Review and recommendations. Current Opinion in Psychology, 16, 109-113.

Gustafsson, H., Hassmén, P., Kenttä, G., \& Johansson, M. (2008). A qualitative analysis of burnout in elite Swedish athletes. Psychology of Sport and Exercise, 9(6), 800-816.

Gustafsson, H., Kenttä, G., Hassmén, P., Lundqvist, C., \& Durand-Bush, N. (2007). The process of burnout: A multiple case study of three elite endurance athletes. International Journal of Sport Psychology, 38, 388-416.

Gustafsson, H., Martinent, G., Isoard-Gautheur, S., Hassmén, P., \& Guillet-Descas, E. (2018). Performance based self-esteem and athlete-identity in athlete burnout: A person-centered approach. Psychology of Sport and Exercise, 38, 56-60.

Hisli, N. (1989). Beck depresyon envanterinin üniversite öğrencileri için geçerliliği, güvenilirliği. Türk Psikoloji Dergisi, 7(23), 313. 
Çam, Z., Kardaş, F., Eşkisu, M., ve Gelibolu, S. (2019). Spor Tükenmişliği Envanteri’nin Türk kültürüne uyarlanması ve psikometrik özellikleri. CBÜ Beden Eğitimi ve Spor Bilimleri Dergisi, 14(1), 79-96.

Hobfoll, S. E., \& Shirom, A. (2001). Conservation of Resources: Applications to stress and management in the workplace. In R. Golembiewski (Ed.) Handbook of Organizational Behavior (pp. 57-80). New York: Marcel Dekker.

Karasar, N. (2011). Bilimsel araştırma yöntemi. Ankara: Nobel yayın dağıtım.

Kelecek, S., Kara, F. M., Kazak Çetinkalp, Z., \& Aşçı, F. H. (2016). Sporcu tükenmişlik ölçeğinin Türkçe uyarlaması. Spor Bilimleri Dergisi, 27(4), 149-161.

Leiter, M. (1989). Conceptual implications of two models of burnout: A response to Golembiewski. Group and Organizational Studies, 14, 15-22.

Pines, A., Aronson, E., \& Kafry, D. (1981). Burnout: From tedium to personal growth. New York: Free Press.

Pituch, K. A., \& Stevens, J. P. (2016). Applied multivariate statistics for the social sciences: Analysis with SAS and IBM's SPSS (Sixth Edition). New York: Taylor \& Francis.

Raedeke, T. D., \& Smith, A. L. (2001). Development and preliminary validation of an athlete burnout measure. Journal of Sport and Exercise Psychology, 23(4), 281-306.

Raedeke, T. D., \& Smith, A. L. (2004). Coping resources and athlete burnout: An examination of stress mediated and moderation hypotheses. Journal of Sport and Exercise Psychology, 26(4), 525-541.

Rosenberg, M. (1965). Society and adolescent self-image. Princeton, NJ: Princeton University Press.

Salmela-Aro, K., Kiuru, N., Leskinen, E., \& Nurmi, J. E. (2009). School burnout inventory (SBI) reliability and validity. European Journal of Psychological Assessment, 25(1), 48-57.

Salmela-Aro, K., Savolainen, H., \& Holopainen, L. (2009). Depressive symptoms and school burnout during adolescence: Evidence from two cross-lagged longitudinal studies. Journal of Youth and Adolescence, 38(10), 1316-1327.

Schaufeli, W. B., Martinez, I. M., Pinto, A. M., Salanova, M., \& Bakker, A. B. (2002). Burnout and engagement in university students: A cross-national study. Journal of Cross-Cultural Psychology, 33(5), 464-481.

Schermelleh-Engel, K., Moosbrugger, H., \& Müller, H. (2003). Evaluating the fit of structural equation models: Tests of significance and descriptive goodness-of-fit measures. Methods of Psychological Research Online, 8(2), 23-74.

Seçer, İ., Halmatov, S., Veyis, F., \& Ates, B. (2013). Okul tükenmişlik ölçeğinin Türk kültürüne uyarlanması: Güvenirlik ve geçerlik çalışması. Turkish Journal of Education, 2(2), 16-24.

Smith, R. E. (1986). Toward a cognitive-affective model of athletic burnout. Journal of Sport Psychology, 8(1), 36-50.

Sorkkila, M., Aunola, K., \& Ryba, T. V. (2017). A person-oriented approach to sport and school burnout in adolescent studentathletes: The role of individual and parental expectations. Psychology of Sport and Exercise, 28, 58-67.

Sorkkila, M., Ryba, T. V., Aunola, K., Selänne, H., \& Salmela-Aro, K. (2017). Sport burnout inventory dual career form for studentathletes: Assessing validity and reliability in a Finnish sample of student athletes. Journal of Sport and Health Science, 19 .

Sorkkila, M., Ryba, T. V., Selänne, H., \& Aunola, K. (2018). Development of school and sport burnout in adolescent studentathletes: A longitudinal mixed-methods study. Journal of Research on Adolescence, 1-19. Doi:10.1111/jora.12453

Sümer, N. (2000). Yapısal eşitlik modelleri: Temel kavramlar ve örnek uygulamalar. Türk Psikoloji Yazıları, 3(6), 49-74.

Yang, H. J. (2004). Factors affecting student burnout and academic achievement in multiple enrollment programs in Taiwan's technical-vocational colleges. International Journal of Educational Development, 24(3), 283-301.

Y1ldı, S. M. (2015). The Relationship between bullying and burnout: An empirical investigation of Turkish professional football players. Sport, Business and Management: An International Journal, 5(1), 6-20.

CBÜ Bed Eğt Spor Bil Dergisi / CBU J Phys Edu Sport Sci 2019: 14(1) 


\section{Ek-1}

\section{Spor Tükenmişliği Envanteri}

Açıklama: Lütfen aşağıda yer alan her bir maddeyi dikkatle okuyarak, şu anda meşgul olduğunuz spor alanı ile bağlantılı olarak düşünüp cevaplayınız. Aşağıda yer alan ifadelerin sizin duygularınızla ne ölçüde uyumlu olduğunu değerlendiriniz Lütfen cevaplarınızı her bir madde numarasinın sol kısmında yer alan "

\begin{tabular}{|c|c|c|c|c|}
\hline $\mathbf{1}$ & $\mathbf{2}$ & $\mathbf{3}$ & $\mathbf{4}$ & $\mathbf{5}$ \\
\hline $\begin{array}{c}\text { Kesinlikle } \\
\text { Katılmıyorum }\end{array}$ & Katılmıyorum & Kararsızım & Katılıyorum & $\begin{array}{c}\text { Tamamen } \\
\text { Katılıyorum }\end{array}$ \\
\hline
\end{tabular}

1. Spor yapmaktan tükendiğimi hissediyorum.

2. Spor yapmak artık ilgimi çekmiyor.

3. Sık sık sporda iyi olmadığım hissine kapılıyorum.

4. Spor yapmakla ilgili sorunlardan dolayı sıklıkla uyku sorunları yaşıyorum.

5. Spora olan ilgimi kaybettiğimi hissediyorum.

6. Sıklıkla sporun bir anlamının olup olmadığını sorguluyorum.

7. Genellikle spor yaparken yapabileceğimin en iyisini yapamadığımı hissederim.

8. Boş zamanlarımda spor yapmakla ilgili sorunları çok fazla düşünürüm.

9. Eskiden spor yapma konusunda daha başarılıydım.

10. Hissettiğim spor yapma baskısı, hayatımın diğer alanlarını olumsuz etkiliyor. 
Çam, Z., Kardaş, F., Eşkisu, M., ve Gelibolu, S. (2019). Spor Tükenmişliği Envanteri’nin Türk kültürüne uyarlanması ve psikometrik özellikleri. CBÜ Beden Eğitimi ve Spor Bilimleri Dergisi, 14(1), 79-96.

\section{Ek-2 DFA işlemine ait yol şeması}

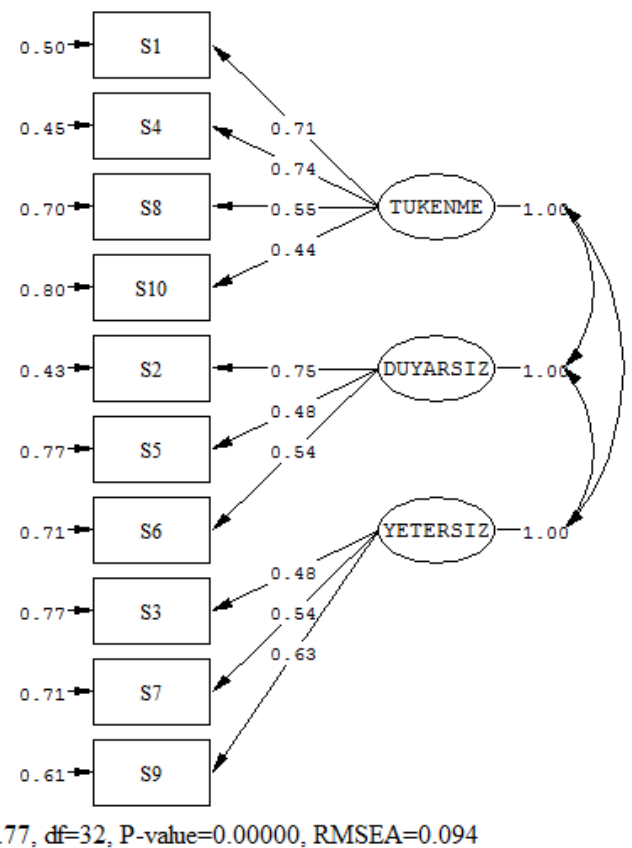

Chi-Square $=102.77, \mathrm{df}=32, \mathrm{P}$-value $=0.00000, \mathrm{RMSEA}=0.094$ 